\title{
Reflections on the Integration of Production and Education in Cultural and Creative Industries
}

\author{
Yu bizhong \\ dept. Media Arts design \\ Beijing Union University \\ Beijing, China
}

\author{
Lin yanmei \\ Beijing Union University \\ Beijing, China
}

\begin{abstract}
The integration of industry and education is the direction of the development of the applied education. For emerging the integration of industry and education about cultural and creative industry, based on the investigation and analysis of the relationship between the school and enterprise, this paper introduces the current situation of the integration of industry and education in the field of cultural and creative industry. It points out that the integration of industry and education is the integration of people, is the integration of corporate culture and school culture, focusing on the communication between teachers and students, schools and enterprises, to seek consensus on strategy, action inclusiveness, flexibility to handle different business needs.
\end{abstract}

Keywords-Integration; Education; Cultural; Creative Industries; Cooperation

The integration of production and education is definitely the direction when developing the applied education, especially vocational education. The integration concept of production and education has been basically accepted by government, schools and enterprises. There are a number of intensive relative theoretical researches. However, there are still many issues to be solved such as how to establish relationship with industries and enterprises in specific practice, and improve and develop mature connections with them.

\section{INTEGRATION STATUS OF PRODUCTION AND EDUCATION IN CHINESE APPLIED EDUCATION}

\section{A. Policy development from "cooperation of school and} enterprise" to "integration of production and education"

The transformation from "cooperation of school and enterprise" to "integration of production and education" reflects people's different recognitions on the relationship of education and industry in different periods. "Cooperation of school and enterprise" believes in the cooperation between school and enterprise while "integration of production and education" believes in the integration of production and education. "Cooperation of school and enterprise" is more specific and microscopic, referring to the cooperation of school and enterprise on personnel training, technology service as well as social training. "Integration of production and education" is more widely. Production not only refers to industry but also enterprise while education contains rich contents of education and teaching. [1]
The State Council's Decision on Accelerating Development of Modern Occupation Education (NO. [2014]19) issued in June 2014 clearly stipulates that "Production and education should be integrated and characteristic education should be run", "to promote the educational transformation in order to link to industrial reforming and upgrading", "Enterprise takes the important role to run a school", and "By 2020, a modern vocational education system with Chinese characteristics and world level should be set up which adapts to the development needs with deep integration of production and education", which means the integration of production and education has been recognized by the government and education authorities at the policy and theoretical levels.

\section{B. Shallow and superficial integration of production and education still exist}

Since the integration policy of production and education was introduced, schools have been talking about the combination of industry and study, the cooperation of school and enterprise and the integration of production and education. Industrial sectors and cooperative enterprises are also talking about the cooperation of school and enterprise as well as the integration of production and education. However, a considerable part of the cooperation of school and enterprise still remains in the shallow and superficial stage, which has not reached the status of deep integration. Dependence on emotion as the link of cooperation of school and enterprise is a common phenomenon currently in China, with the real interest mechanism not yet established. [2]

First, though integration policy of production and education has been issued, there still lacks enforcement regulations. Effectiveness and reward are still on paper, which cannot be operated. As to the issues such as who will evaluate the effectiveness, how to judge effectiveness, who will reward, and where the resources are, there are no answers. The Law of Vocational Education in China is more likely to regulate the vocational education of schools. Article Six stipulates that "Enterprises should implement the legal duty of vocational education: People's governments at all levels should include vocational education development into national economic and social development plans. Industry organizations, enterprises and institutions should fulfill the duty of vocational education according to law". However, enterprises are not given the legal status as education institutions. Enterprises are only the participants of vocational education, but not the main bodies of 
running schools. In this regard, Article Six has no real legal binding on enterprises.

Second, there is no relative long-term interest mechanism between schools and enterprises. The dominant and discourse power of the cooperation of school and enterprise is monopolized by the educational circles, and industrial enterprises are marginalized. In the words of Ge Daokai, Director-General of the Department of Vocational Education and Adult Education, Ministry of Education, "Enterprises have always participated in vocational education as volunteers and helpers for a long time. Since they come to help, they can do more, they can do less, and they can even do nothing, there is no ground for blame". [4]

Comparatively speaking, the German Law of Vocational Education stipulates that enterprises that are qualified to implement the "dual system" vocational education are called "educational enterprises". These enterprises have to take the social responsibility of education, and at the same time, they can enjoy special tax incentives and financial subsidies. [4]

\section{No enough researches on the integration of production and education in cultural and creative industries}

Cultural and creative industries are emerging industries with creativity as the core under the background of economic globalization, which emphasize an industry that a main culture or cultural factor develops and markets intellectual property by individuals (teams) through technology, innovation and industrialization.

The most core factors of "cultural and creative industries" are liberation of human creativity. Personal creativity and quality is the most critical part of the entire cultural and creative industries and is the basis of industrial chain. Painters, writers and artists are all freelancers.

Domestic cultural and creative industries are still young emerging industries. Film, television and other industries have formed an incomplete industrial chain. The entrance of Ali, Youku and other internet companies makes the scale of industries grows rapidly. However, the vast majority of enterprises in creative design industries are still small and micro ones. The main body of creative industries is still individual artist, and the industry of culture and art is an industry of individuals.

On the one hand, the integration of production and education in cultural and creative industries is industry, and on the other hand it is university. The majors related to culture and creativity in universities can be divided into three categories: one is art design, one is cultural industry operation and management, and the other is entertainment, recreation and service. Art design talents are the creators of creative industries and the core of creativity. They have strong professional and targeted abilities. The second and the third categories belong to economic management. They usually take majors of economics or management as the basis, and develop through adding courses related to cultural and creative industries. The target is to cultivate talents to operate cultural and creative industries.

The characteristics of cultural and creative industries determine the special rules of the integration of production and education in this field. It's necessary to research on the features and to summarize the rules through continuously discovering and practicing. This article discusses the existing issues as well as the solutions of the integration of production and education in art design filed.

\section{THE CHARACTERISTICS OF THE INTEGRATION OF Production AND EDUCATION IN CULTURAL AND CREATIVE INDUSTRIES}

The integration of production and education is a social systematic project. Compared with the integration of production and education in other industries, the relationship between schools and enterprises is more complicated in the integration of production and education in cultural and creative industries. Here are the specific performances:

\section{A. Small and micro cultural and creative enterprises are the major objects of the cooperation of university and enterprise}

The cooperation of university and enterprise in cultural and creative industries is different from the large-scale organization methods in traditional industries. In cultural and creative industries, small and micro enterprises are the major components of the industry and the main forces of the cooperation of school and enterprise. The brand new way of thinking in cultural and creative industries makes creative enterprises prefer individualized survival. The intellectual economic characteristic of "creativity" is the main reason why most enterprises are small and micro. In this way, there are corresponding needs for individual talents. Small and micro enterprises in cultural and creative industries are limited by human resources, space and investments. They often have strong willingness of cooperation, but with limited ability to undertake students. It is of practical significance to explore the cooperation of school and enterprise with multi subjects.

\section{$B$. Organizations are diversified in the industries related to culture and creativity}

Organizational relationship of industries related to culture and creativity is complex and diversified. Compared with traditional industries, it is more difficult to rely on industrial associations to promote the integration of production and education in cultural and creative industries. Some organizations in cultural and creative industries derive and develop based on traditional industries while others are formed during the development of industries whose organizational methods are relatively loose. Take interaction design as an example, there are not only interaction design associations and experience design associations which have developed rapidly in recent years, but also traditional industrial design associations, internet associations and other IT organizations.

\section{Enterprises have unclear status and power to run schools}

Enterprises have unclear status and power to run education, and their reasonable rights cannot be guaranteed. This is why both sides of school and enterprise cannot be really integrated during practices. Decision makers of enterprises cannot decide how to input and how much to input. Only by benefiting both sides of "production" and "education" can it guarantee the 
integration of production and education as well as continuous development.

Currently, the main needs of the integration of production and education are in school rather than enterprises. Enterprises are operational organizations for making profits. The reason for enterprises to participate in running schools is to obtain talents and improve operational abilities of enterprises. Cooperation with schools is more like a responsibility and public welfare at the view of development. For universities lacking industrial background, the integration of production and education is crucial.

\section{Protection of intellectual property during the integration of production and education in cultural and creative industries}

Creative design enterprises have developed by relying on their "creative products". Students can have more chances to be exposed to creative ideas as well as products in design when learning in design enterprises. These products in design do not have the conditions to apply for the protection of intellectual property. Once the creative ideas leak, there will be great losses for enterprises. Enterprises are hard to avoid losses even if they can protect the intellectual property through laws. Thus, a considerable part of enterprises are not willing to accept students to participate in actual design work. In teaching activities, they are more likely to share and discuss decrypted cases with teachers and students. The issue of intellectual property cannot be avoided during the integration process of production and education in cultural and creative industries.

\section{E. Deep integration of thought and action for both parties of production and education}

In actual practices, the integration of production and education is eventually realized through the integration of thoughts and action of students, teachers, responsible managers and employees.

Enterprise managers hope to make better development through cooperation from the strategic view of enterprise development. There are usually specific departments or people to negotiate with schools in these enterprises. They can do specific work such as implementation of cooperation contents, tutor selection and arrangement of teaching task. Usually, enterprises depend on business departments to realize profits. Compared with business departments, the cooperation departments of school and enterprise have lower priority, with limited rights to allocate employees or other resources. In addition, cultural and creative field does not have professional title system which is recognized by school system. At policy level, it is very difficult for professional technicians of large scale cultural and creative enterprises to be involved in school teaching. It is relatively easier for enterprise owners or managers to be recognized during cooperation of school and enterprise. However, the management major does not represent the majors to do specific work. In this regard, small and micro enterprises have advantages since owners of small and micro enterprises are not only managers but also the ones with professional skills in the field of art. During integration process of production and education, they are more likely to meet the requirements of external teachers and reach cooperative consensus. The deficiency lies in limited scope and content of cooperation since small and micro enterprises have limited resources.

In order to cultivate talents, schools hope to improve "double teaching" abilities of teachers through the integration of production and education. In ideal status, full-time teachers, designers and technicians can get closer, build mutual trust and realize the integration of production and education during the communication process. However, in reality, evaluation system of school lacks effective incentive policy while enterprise evaluation has not cover this aspect. Without system guarantee and financial support, both sides input limited time and energy. Besides, the difference of vocational experiences between two sides leads to the result that the communication remains at the level of basic technical training. It is urgent for teachers to master industrial discipline, art standard and project experience that cannot be quantified in art field. Deep communication and accumulation of practical experience are needed to obtain them.

During the integration process of production and education, the attitudes of students are important. Learning motivations of students have certain connections to teaching methods, course organizations and degree of strictness. The most important impact is from environment. After students enter enterprises, most of them will improve learning motivation in the context of corporate culture.

\section{Suggestions to Promote Integration of Production \\ AND EDUCATION IN CULTURAL AND CREATIVE INDUSTRIES}

The essences of the integration of production and education in cultural and creative industries are the integration of human being as well as the integration of enterprise culture and school culture. Production and education need to seek consensus on strategy, to have mutual inclusion in action, and to flexibly handle different requirements. It is suggested to solve the following existing problems in the integration practices of production and education:

\section{A. Owners and operators of enterprises interact with managers of schools to promote the integration of management}

To expand the cooperation of production and education and optimize current management system of school based on industrial features and development laws. In this way, effective and sustainable innovative cooperation system of school and enterprise can be formed and policy can be turned into system. School has formed a process of teaching management and operation after so many years. However, there is more industrial and market information during the integration of production and education that requires teaching activities to deal with the changes of market more flexibly. At this moment, the contradiction of current teaching management system and art major organization is brought out.

Art creation emphasizes the emotional integration. During art teaching process, teachers will inspire and lead students. Students will gradually discover and learn techniques and thoughts during conflict and collision of thoughts. This process has strong personality, which is hard to control by developing strict plans. Within current teaching monitoring system, negative evaluations such as poor planning and unscheduled 
teaching have led to the result that teachers are more likely to adopt ways conforming management laws instead of creative teaching rules to teach.

\section{B. Promote practical abilities of teachers during the communication and cooperation with enterprises}

The practical experience of enterprise employees in managing design projects and the teaching experience of school teachers are necessary fortunes during the cultivating process of talents. In nowadays, school teachers usually lack industrial experiences. They lack the process from theory to practice and then from practice to theoretical development. To strengthen the communication with enterprise employees can help school teachers obtain practical experience of artistic creation. The artistic creation level and teaching ability of teachers can be improved on the whole.

In order to make up the shortage of practical ability of school teachers, teachers in artistic field need to conduct fulltime creation for no less than half a year once every two years. Teachers and students can complete such creation by taking part in practical design projects. It can not only solve the issue of teacher shortage, but also manage students when they work in enterprises, provided that enterprises are willing to accept the joint learning of teachers and students, or teachers are able to carry on related design projects. As an encouraging measure, school needs to provide special financial support to this activity and guarantee time and institutional arrangements.

\section{Students integrate in enterprises gradually during creative practices}

Most students both look forward to and worry about job and career life. Students can integrate in enterprises during creative practices, which helps mutual understandings between students and enterprises. The energy of young people and their adaptability can be strengthened in the environment of enterprise culture. The cooperation of school and enterprise creates conditions for students to be deeply involved in industrial practice, which is also the basis of the integration of production and education. During the cooperative process, not only the professional abilities of students can be checked, but also the abilities of communication and learning as well as professional spirits can be cultivated.

\section{Integrate the gene of "creativity" in cultural and creative enterprises with gene of school culture}

The integration of production and education is the integration of enterprise culture and school culture. The development process of cultural and creative industries is the innovative development of enterprises. Artists create enterprises with diligence and wisdom, and also create multivariate, colorful and individual enterprise culture. Creativity determines the survival of creative enterprises. The integration of production and education not only needs to research on the general characters of enterprises, but also should focus on the differences, distinct values of enterprise culture, social responsibility as well as operational idea. The cultural integration of production and education is beneficial for schools and enterprises to agree with each other on the strategic perspective of cultural development, and enable them to consider questions from the perspective of the other side. What's more, inclusiveness is necessary in action to handle the requirements of different enterprises flexibly so as to avoid unnecessary internal frictions caused by cultural conflicts, and to comply with the development laws of cultural and creative industries, thus cultivating cultural and creative talents with "creativity".

\section{CONCLUSION}

The target of the integration of production and education in cultural and creative industries is to realize human integration of creative circle and educational circle. The integration has multiple levels and dimensions, which is not to simply complete a project, but a continuous integration process of thoughts. Mutual understandings are strengthened continuously during the integration, with invisible barriers between industries removed so as to realize complementary advantages and coordinated development.

\section{REFERENCES}

[1] Guan Dan, Analysis on the concept of "Cooperation of schools and enterprises" and "Integration of production and teaching", Vocational Education Journal, 2016 (In Chinese)

[2] $\mathrm{Yu}$ Zhongli, Analysis on operation mechanism of schools and enterprises, Vocational Educational Forum, 2009(In Chinese)

[3] Jiang Dayuan, Study on contemporary trends of vocational education in the world, Beijing, Electronics Publishing House, 2012(In Chinese)

[4] Wu Zhuping, From cooperation of schools and enterprises to integration of production and education: a real deal for vocational schools, Academic Journal of Huanggang Vocation School, 2015(In Chinese) 